\title{
Relationship between circulating levels of cortisol at slaughter and changes of some parameters of the camel meat during ageing
}

\author{
Rabab Tabite ${ }^{1}$, Abdelilah Lemrhamed ${ }^{1}$, Najia El Abbadi ${ }^{2}$, Abderrahmane Belhouari $^{3}$, Bernard Faye ${ }^{4}$, \\ Mohammed El Khasmi ${ }^{1 *}$ \\ ${ }^{1}$ Laboratory of Physiopathology and Molecular Genetics, Faculty of Sciences Ben M'Sik, University Hassan II of Casablanca, PB 7955 \\ Sidi Othmane, Casablanca, Morocco, ${ }^{2}$ Unit of Radio-Immuno-Analysis/Division of Life Sciences, National Center for Energy, Science \\ and Nuclear Techniques, PB 1382 RP 10001, Rabat, Morocco, '² aboratory of Ecology and Environment, Faculty of Sciences Ben M'Sik, \\ University Hassan II of Casablanca, PB 7955 Sidi Othmane, Casablanca, Morocco, ${ }^{4}$ FAO/CIRAD-ES, Campus International de Baillarguet, \\ TA C/dir B 34398 Montpellier, France
}

\section{A B S T R A C T}

Relationship between serum levels of cortisol at slaughter and changes of some parameters of meat was investigated in 50 male camels, during ageing for 10 days at $4 \pm 1^{\circ} \mathrm{C}$. Blood was sampled at slaughter to determine serum levels of cortisol and oblique abdominal external muscle was collected after slaughter to analyze $\mathrm{pH}$, electrical conductivity (EC), drip loss (DL), cooked loss (CL), moisture, solids, ashes, protein total, calcium (Ca), phosphorus ( $\mathrm{Pi})$, magnesium $(\mathrm{Mg})$, sodium $(\mathrm{Na})$, potassium (K), catalase activiry (CATa), malondialdehyde (MDA), shrinkage, R-value and total haem pigment (THP) at days 0 (four hours postmortem), 5 and 10 of refrigerated storage. The camels were divided into 3 groups $(\mathrm{Gr})$ with different serum levels of cortisol at slaughter (low, high and very high levels): Gr1 (13.07-67.9 ng/mL, $\mathrm{n}=24), \mathrm{Gr} 2$ (80.29-107.21 ng/mL, $\mathrm{n}=$ 7) and $\mathrm{Gr} 3$ (133.7-198.04 ng/mL, $\mathrm{n}=19)$. Compared to $\mathrm{Gr} 1, \mathrm{Gr} 2$ and $\mathrm{Gr} 3$ had a significant $(\mathrm{P}<0.05)$ increase of $\mathrm{pH}, \mathrm{EC}, \mathrm{DL}, \mathrm{CL}$, THP, dimensional shrinkage and MDA, and a significant $(\mathrm{P}<0.05)$ decrease of CATa at the $5^{\text {th }}$ and $10^{\text {th }}$ postmortem days. However, the bleeding efficiency, moisture, ashes, $\mathrm{R}$-value and levels of $\mathrm{Ca}$, $\mathrm{Pi}$, $\mathrm{Na}$, $\mathrm{K}$ and total protein showed no significant differences between twoo cortisol groups. The antemortem circulating levels of cortisol were positively correlated with postmortem $\mathrm{pH}, \mathrm{EC}, \mathrm{DL}, \mathrm{CL}, \mathrm{THP}$, dimensional shrinkage and MDA, and negatively correlated with CATa. The analysis of circulating cortisol at slaughtering may predict the quality and oxidant stress status of camel meat during postmortem cold storage.

Keywords: Cortisol; Oxidant stress; Meat quality; Minerals; Proteins; Camel

\section{INTRODUCTION}

The stress of transport and handling, as well as waiting at the slaughterhouse induce an increase of cortisolemia, and creatine kinase and lactate in muscle (Kannan et al., 2000). Preslaughter stress (handling, transport, unloading and lairage) is responsible for a glycogen depletion in the muscle that can reduce the quality of meat (Immonen et al., 2000; Warriss, 2003).

Compared to other red meats, that of the dromedary is characterized by low levels of fat and cholesterol, and it is therefore beneficial for human health (Gheisari and Ranjbar, 2013). Currently, researchers are much more interested in improving the quality parameters of camelina meat, such as its water retention capacity (WHC), tenderness, color and juiciness (Engy, 2017). The ultimate $\mathrm{pH}$ of muscle measured $24 \mathrm{~h}$ postmortem $(\mathrm{pHu})$ is the important indicator of the meat quality at the commercial level. The pHu is able to impact color, WHC and tenderness of meat, and it's influenced by the antemortem levels of glycogen and the postslaughter levels of lactate in the muscle (Gregory, 2003). Like other species, the quality of meat in the dromedary camel, includes fat content, pHu, color, WHC and tenderness (Kadim et al., 2008). In this species, pre-slaughter stress (transportation, novelty, fasting, loading, unloading, stockage density and lairage) had effects on metabolism as demonstrated by high circulating levels of adrenaline and cortisol resulting in a

\footnotetext{
${ }^{*}$ Corresponding author:

Mohammed El Khasmi, Laboratory of Physiopathology and Molecular Genetics, Faculty of Sciences Ben M'Sik, University Hassan II of Casablanca, PB 7955 Sidi Othmane, Casablanca, Morocco. E-mail: elkhasmimohammed@gmail.com
} 
depletion of glycogen in the muscle, causing high ultimate pH, drip loss and lipid peroxidation (Saeb et al., 2010; El Khasmi et al., 2010; 2015; Barka et al., 2016; Lemrhamed et al., 2018a; 2018b).

During ageing the camel meat showed a significant lipid oxidation associated to a high levels of malondialdehyde (MDA) and low catalase activity (CATa) (Tabite et al., 2018). This oxidation interferes with the integrity and safety of meat through the formation of potentially toxic compounds (Silva et al., 1999) such as MDA. Cold preservation of meat is known by an imbalance between antioxidants and prooxidants leading to an exaggerated formation of reactive oxygen species in front of an antioxidant system that is not effective (Hur et al., 2004). The aim of this work was to investigate the relationship between the circulating levels of cortisol at slaughter and some parameters of the camel meat such as $\mathrm{pH}$, electrical conductivity (EC), drip loss (DL), cooked loss (CL), moisture, solids, ashes, proteins, calcium $(\mathrm{Ca})$, phosphorus (Pi), magnesium $(\mathrm{Mg})$, sodium $(\mathrm{Na})$, potassium $(\mathrm{K}), \mathrm{MDA}$, CATa, shrinkage, R-value and total haem pigment (THP) during ageing for 10 days at $4 \pm 1^{\circ} \mathrm{C}$.

\section{MATERIALS AND METHODS}

\section{Animals}

This investigation was carried out during April and May, the average ambiant $\mathrm{T}^{\circ}$ was $20^{\circ} \mathrm{C}$, the average humidity was $71 \%$, and the average wind speed and rainfall were $18 \mathrm{~km} / \mathrm{h}$ and $1 \mathrm{~mm}$ respectively. In the municipal slaughterhouse of Casablanca located to the West of Morocco (North of Africa, latitude $33^{\circ} 34^{\prime} 42.44^{\prime \prime} \mathrm{N}$, longitude $7^{\circ} 36^{\prime} 23.89^{\prime \prime}$ O), 50 male camels in total ( 5 to 8 years, 300 to $400 \mathrm{~kg}$ ) were used. According to their serum levels of cortisol, the camels were divided into 3 groups (Gr) which exhibited different serum levels of cortisol at slaughter (low, high and very high levels): Gr1 (13.07-67.9 ng/mL, $\mathrm{n}=24), \mathrm{Gr} 2$ (80.29$107.21 \mathrm{ng} / \mathrm{mL}, \mathrm{n}=7)$ and $\mathrm{Gr} 3(133.7-198.04 \mathrm{ng} / \mathrm{mL}$, $\mathrm{n}=19)$. These animals were road transported by truck for a distance of 72 to $80 \mathrm{~km}$ and an average speed of $60-65 \mathrm{~km} / \mathrm{h}$. The loading density was $2.6 \mathrm{~m}^{2} /$ camel. By using the formula cited by the Farm Animal Welfare Council (FAWC, 1991), the area in square metres is equal to 0.0315 mutiplied by the live weight of animal in $\mathrm{kg}$ to the power of 0.67 . According to the calculated value $\left(2.5 \mathrm{~m}^{2}\right)$, the loading density used in this investigation has respected the animal welfare. The trucks used to transport the camels were devoid of ceiling and roof, and its floor and surrounding walls were made of iron. The camels were transported without any bedding materials. During the transport, they did not have access to water and food, they were placed in the trucks in a squatting position and turned to the side, and the forelegs were tightened by a rope at knee level. The road was paved from the start until the end of the journey. On arrival, the dromedaries were carefully unloaded to avoid any stress, and were then calmly taken to the stall area at the slaughterhouse.

On arrival and after unloading, the camels were subjected to a rest period for 13 to 18 hs in the waiting zone under a stocking density of $4 \mathrm{~m}^{2} /$ camel. They were not isolated from noise and human activity and didn't have access to water and food. After the waiting duration, the animals were guided inside the slaughter room at 7:00 am, to be slaughtered according to the routine Halal procedure without any prior stunning. They were placed in a squatting position on the floor with the forelegs tied with a rope at the knees. The heads were fixed in a caudal position and an adult Muslim made the animals quickly bleed by section of the jugular veins, carotid arteries, trachea and esophagus without severing the spinal cord. After slaughter, the animals were suspended, the skin, head, legs and viscera were isolated, and the carcasses were placed in the refrigerator at $4{ }^{\circ} \mathrm{C}$ and in the dark for $12 \mathrm{~h}$.

\section{Blood sampling}

To determine the serum levels of cortisol, blood was collected at slaughter $(07 \mathrm{am})$ directly in dry tubes which were kept in ice. Serum was separated within $40 \mathrm{~min}$ of collection by centrifugation at $5^{\circ} \mathrm{C}$ for $15 \mathrm{~min}$ at $750 \mathrm{xg}$, then stored in $1.5 \mathrm{ml}$ Eppendorf tubes at $-20^{\circ} \mathrm{C}$ until analysis.

\section{Muscle removal}

After slaughtering and veterinary inspection, approximately $450 \mathrm{~g}$ of oblique abdominal external muscle (musculus abdominis obliquus externus) were collected at $10 \mathrm{~h}$ a.m within $3 \mathrm{~h}$ postmortem from the right side of carcasse of each animal. The muscle samples were packed in zipped plastic bags and then transported to $4^{\circ} \mathrm{C}$ for $10 \mathrm{~min}$ in the cooler to the laboratory. Fat and connective tissue were removed and lean meat samples were divided into 3 portions: $\mathrm{P} 4 \mathrm{~h}$, P5d and P10d which were packaged separately in plastic bags and kept in a refrigerator $\left(4 \pm 1^{\circ} \mathrm{C}\right)$ for $4 \mathrm{~h}$ postslaughter, $5 \mathrm{~d}$ and $10 \mathrm{~d}$ postmortem respectiveley. All meat portions were divided into 4 parts: p1 (42 g) to analyze $\mathrm{pH}, \mathrm{DL}, \mathrm{CL}$ and EC; p2 (5g) to analyze moisture, solids, ashes, $\mathrm{Ca}, \mathrm{Pi}, \mathrm{Mg}$, $\mathrm{Na}$ and $\mathrm{K} ; \mathrm{p} 3$ (17 g) to determine protein, MDA and CATa, and p4 (7.5 g) for estimate R-value, shrinking and THP at each postmortem ageing time. These parts were packaged in a sterile polythene bags, labelled and then were placed at $4 \pm 1^{\circ} \mathrm{C}$ for $10 \mathrm{~d}$ and all measurements were assessed in duplicate of each parameter.

To analyze total protein, MDA and CATa at different ageing times, meat samples were added to a phosphate buffer solution (0.1 M, pH 7.4) (500 mg/5 ml), then were 
homogenized at $4^{\circ} \mathrm{C}$ for $30 \mathrm{~s}$. The homogenates were centrifuged at $5000 \mathrm{rpm}$ for $15 \mathrm{~min}$, and the supernatants were stored at $-80^{\circ} \mathrm{C}$ until assay.

\section{Cortisol analysis}

At the national center for nuclear science and technical energy in Maâmoura, Morocco, serum cortisol concentrations were measured by kits marketed using radiolabelled cortisol ${ }^{125} \mathrm{I}$ (DIAsource, Immunoassays S.A., Nivelles, Belgium). These kits have proven to be effective in previous investiagations on camels (El Khasmi et al., 2013; 2015; Lemrhamed et al., 2018a). Limits of detection were included in the areas of validation for cortisol analysis, and precision in the standard curve following sample dilution, inter- and intra-assay coefficients of variation results were considred.

\section{pH and electrical conductivity measurement}

To measure the meat $\mathrm{pH}$, samples ( $2 \mathrm{~g})$ were crushed and homogenized by a porcelain mortar using $20 \mathrm{~mL}$ neutralized 5-mM sodium iodoacetate. The $\mathrm{pH}$ meter was calibrated with $\mathrm{pH} 4$ and 7 standards, and the $\mathrm{pH}$ value was measured at $18-20^{\circ} \mathrm{C}$ by a standardized glass electrode. The EC was measured with a conductivity meter (model Hanna EC 215 connected to an electrode of the four rings HI 76303) which is microprocessor type LF 196 equipped with a conductivity cell. The device is calibrated with potassium chloride solution $(0.01 \mathrm{~mol} / \mathrm{L})$ whose the $\mathrm{EC}$ is known for a reference temperature of $25^{\circ} \mathrm{C} .5 \mathrm{~g}$ of muscle were ground and the homogenates were centrifuged at 18,000 x $\mathrm{g}$ for $30 \mathrm{~min}$. The volume of juice recovered is supplemented to $20 \mathrm{~mL}$ with pure water to have a sufficient volume to plunge the conductivity cell. The EC values were adjusted automatically in relation to the temperature of the sample. The values of Measurements made on pure water used to dilute meat juices were deduced from the conductivity values and were expressed in $\mathrm{mS} / \mathrm{cm}$.

\section{Drip loss and cooking loss}

DL was measured using the method of Pohja and Niinivaara (1957). Meat samples weighing $5 \mathrm{~g}$ were placed between two filter papers (Whatman No. 1) and pressed at $10 \mathrm{~kg}$ for $5 \mathrm{~min}$. Then, meat samples were separated from the filter papers and reweighed. The percentage of weight loss after cold storage was determined from the difference in muscle weight before and after ageing.

To analysis the CL (Honikel, 1998), meat samples (30 g) were placed in polyethylene bag and totally immersed without adding ingredients or fat in a water bath at $70^{\circ} \mathrm{C}$ for $90 \mathrm{~min}$. The internal temperature monitored using a thermometer during boiling was $97^{\circ} \mathrm{C}$. After cooking, the samples were cooled to room temperature for $40 \mathrm{~min}$ in its exuded fluids and then removed and dried slightly with blotting paper and reweighed. CL (\%) were determined by the difference between the sample mass before cooking and mass after cooking and was expressed as a percentage of the initial weight of sample.

\section{Moisture, solids, ashes and minerals analysis}

The chemical composition of camel meat was analyzed according to the standard methods of Association of Official Analytical Chemists (AOAC, 2000).

$\mathrm{Ca}$, Pi and Mg were cholorimetrically analyzed in ashes after acidification (JENWAY 6320D Spectrophotometer, Model 6320D) using commercially available kits (CHRONOLAB, Switzerland). $\mathrm{Na}$ and $\mathrm{K}$ were determined in ashes after acidification by flame photometry using standard solutions prepared by dilution of stock solutions of $\mathrm{Na}$ and $\mathrm{K}$.

\section{Analysis of total protein, malondialdehyde and catalase activity}

The total protein (g protein/100 g sample) was measured in meat samples of $10 \mathrm{~g}$ by the Kjeldahl method using the factor 6.25 for conversion of nitrogen to crude proteins.

The MDA was estimated by the method of Botsoglou et al. (1994). Half a mL of the homogenate having been prepared from a sample of $5 \mathrm{~g}$ was mixed with $0.5 \mathrm{ml}$ of trichloroacetic acid (TCA) $20 \%$ and $1 \mathrm{ml}$ of thiobarbituric acid (TBA) $0.67 \%$. The mixture was incubated in a water bath at $100^{\circ} \mathrm{C}$ for $15 \mathrm{~min}$, then cooled, and after addition of $4 \mathrm{ml}$ of $\mathrm{n}$-butanol, the mixture was centrifuged for $15 \mathrm{~min}$ at $3000 \mathrm{rpm}$. The absorbance of the supernatant was measured at $530 \mathrm{~nm}$ against the blank. The concentration of MDA was calculated according to the formula:

$$
\mathrm{C}=103 \mathrm{OD} / \varepsilon \chi \mathrm{LD}
$$

where C: concentration of MDA in $\mu \mathrm{mol} / \mathrm{mL}$; OD: optical density read at $530 \mathrm{~nm}$; $\varepsilon$ : molar extinction coefficient of the $\mathrm{MDA}=1.56 \times 10^{5} / \mathrm{M} / \mathrm{cm}$; L: optical path length $=$ $0.779 \mathrm{~cm} ; \chi$ : volume of the sample $(\mathrm{mL}) ; \mathrm{D}$ : dilution factor.

The CAT activity in meat samples was estimated by the method of Aebi (1974). An enzyme fraction was prepared from $2 \mathrm{~g}$ of the sample which was cut and homogenized in three volumes of phosphate buffer $(0.1 \mathrm{M}, \mathrm{pH} 7.4)$ by homogenizer. The homogenate obtained was centrifuged at 2,000 $\mathrm{rpm}$ for $30 \mathrm{~min}$ at $4^{\circ} \mathrm{C}$ and on the final supernatant the activity of the CAT was analyzed. The disappearance of $\mathrm{H}_{2} \mathrm{O}_{2}$ was assisted colorimetrically at $240 \mathrm{~nm}$ for $2 \mathrm{~min}$ according to the following formula:

$$
(2.3033 / \mathrm{T}) \times(\log \mathrm{A} 1 / \mathrm{A} 2)
$$

Where A1: absorbance at the first minute; A2: absorbance at the second minute; $\mathrm{T}$ : time interval in minutes. 
The CAT activity was defined as the decrease of $\mathrm{H}_{2} \mathrm{O}_{2} / \mathrm{min} / \mathrm{g}$ of muscle using a molar extinction coefficient of $0.041 / \mathrm{mM} / \mathrm{cm}$.

\section{Estimation of R-value, shrinkage and total haem pigment}

To evaluate meat R-value (Honikel and Fisher, 1977), $2 \mathrm{~g}$ of muscle samples were homogenized in $10 \mathrm{~mL}$ of $1 \mathrm{M}$ perchloric acid and filtred. The filtrate $(0.1 \mathrm{~mL})$ was diluted with $4.9 \mathrm{~mL}$ of $0.1 \mathrm{M}$ phosphate buffer $(\mathrm{pH} 7.0)$. The optical density at $250 \mathrm{~nm}$ (for IMP) and that at $260 \mathrm{~nm}$ (for ATP) were spectrophotometrically determined (JENWAY 6320D Spectrophotometer, Model 6320D) and the R-value was evaluated by the ratio of 250:260.

To estimate meat shrinkage, width and length of the same

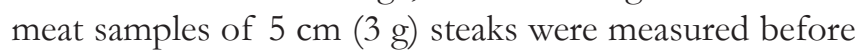
and after cooking, to measure the reduction in width and length, then the dimensional shrinkage according to the standard methods of (AOAC, 2000).

To determine THP from ground meat (Warriss (1979), samples $(2.5 \mathrm{~g})$ were mixed with acetone $(10 \mathrm{ml})$, distilled water $(0.5 \mathrm{ml})$ and $\mathrm{HCl}(0.25 \mathrm{ml})$ in a beaker of $50 \mathrm{ml}$, then the mixtures were covered with parafilm and maintained overnight at $4^{\circ} \mathrm{C}$ in the dark. After filtration of mixtures, the optical density was spectrophotometrically determined at 640 (JENWAY 6320D Spectrophotometer, Model 6320D), using a blank solution ( $80 \%$ acetone, $2 \% \mathrm{HCl}$ and $18 \% \mathrm{H}_{2} \mathrm{O}$ ). The absorbance was multiplied by 680 to estimate the concentration of THP $(\mu \mathrm{g} / \mathrm{g}$ of meat).

\section{Statistical analysis}

The data were expressed as Mean \pm standard error (SE) and analysis of variance (ANOVA) of the General Linear Models procedure of the Statistical Analysis System Software (SAS, 2005) was used to analyze the data. To search if significant differences existed among groups and ageing times, Duncan's multiple range test was used and $\mathrm{P}<0.05$ was considered as the level of significance. Pearson's correlation tests were used to analyze correlations between parameters.

\section{RESULTS}

$\mathrm{pH}$, drip loss, cooking loss and electrical conductivity Compared to low cortisol camels (Gr1), high (Gr2) and very high $(\mathrm{Gr} 3)$ ones showed a significant $(\mathrm{P}<0.05)$ increase of $\mathrm{pH}$, DL, CL and EC at 5 and $10 \mathrm{~d}$ postmortem during storage at $4 \pm 1{ }^{\circ} \mathrm{C}$. In Gr1, Gr2 and Gr3 values measured at the $5^{\text {th }} \mathrm{d}$ were respectively $5.60 \pm 0.11,6.60 \pm 0.11$ and $6.65 \pm 0.11$ for $\mathrm{pH}$, $9.23 \pm 1.12,12.56 \pm 1.45$ and $13.11 \pm 1.41$ for DL $(\%), 23.78 \pm 1.53$, $27.67 \pm 1.63$ and $28.23 \pm 1.57$ for CL $(\%)$ and $6.75 \pm 2.24$, $13.16 \pm 2.52$ and $13.87 \pm 2.56$ for EC (mS/cm) (Fig. 1).

\section{Moisture, solids and ashes}

As showed in Fig. 2, no significant differences among Gr1, Gr2 and Gr3 were observed in moisture, solids and ashes during all cold storage period. Mean values (\%) registered at $5 \mathrm{~d}$ postpartum were respectively $7.26 \pm 0.14,7.34 \pm 0.17$ and $7.33 \pm 0.17$ for moisture, $2.74 \pm 0.14,2.67 \pm 0.17$ and $2.67 \pm 0.16$ for solids and $1.14 \pm 0.1,1.13 \pm 0.08$ and $1.13 \pm 0.09$ for ashes (Fig. 2).

\section{Total protein and minerals}

Groups 1, 2 and 3 showed no significant differences of meat levels of protein total, $\mathrm{Ca}, \mathrm{Pi}, \mathrm{Mg}, \mathrm{Na}$ and $\mathrm{K}$ during the cold storage period (Figs. 3 and 4). In these groups, protein levels $(\mathrm{g} / 100 \mathrm{~g})$ were $23.34 \pm 3.11,22.42 \pm 2.16$ and $23.11 \pm 2.12$ respectiveley at $5 \mathrm{~d}$ postmortem (Fig. 3). At the same stage, $\mathrm{Mg}$ levels $(\mathrm{mg} / 100 \mathrm{~g})$ in groups 1, 2 and 3 were $42.43 \pm 3.15,40.72 \pm 3.42$ and $40.03 \pm 3.33$ respectiveley

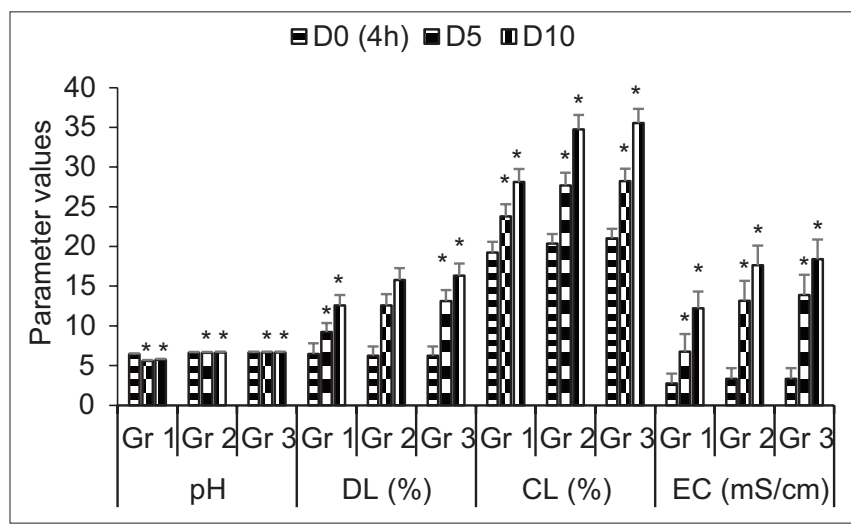

Fig 1. Impact of ageing on $\mathrm{pH}$, drip loss (DL) and cooking loss (CL) in meat at $4 \mathrm{~h}$ postslaughter and 5 and $10 \mathrm{~d}$ postmortem during storage at $4 \pm 1{ }^{\circ} \mathrm{C}$, in 3 groups (Gr) of camels with different serum levels of cortisol at slaughter [Gr1 (13.07-67.9 ng/mL, $n=24)$, Gr2 (80.29-107.21 ng/mL, n=7) and Gr3 (133.7-198.04 ng/mL, n= 19)]. (Means $\pm \mathrm{SE},{ }^{*} \mathrm{P}<0.05$, comparison between groups at the same day of cold storage).

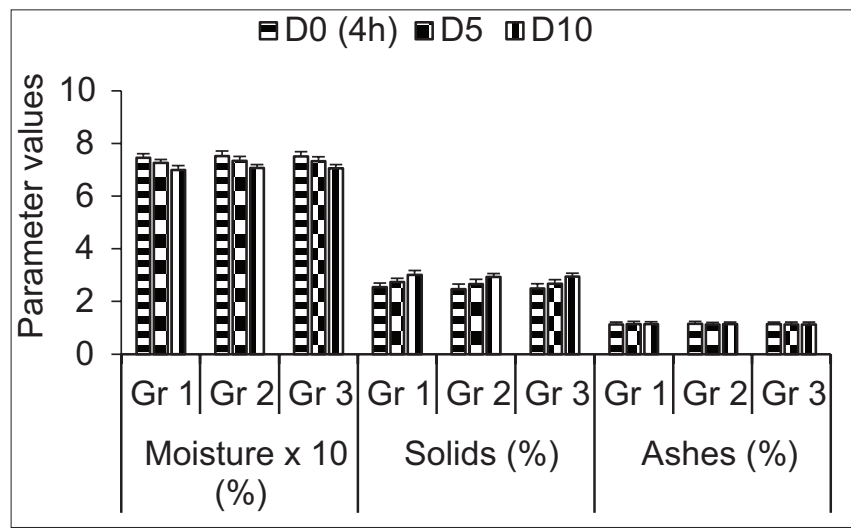

Fig 2. Impact of ageing on moisture, solids and ashes in meat at $4 \mathrm{~h}$ postslaughter and 5 and $10 \mathrm{~d}$ postmortem during storage at $4 \pm 1^{\circ} \mathrm{C}$, in 3 groups $(\mathrm{Gr})$ of camels with different serum levels of cortisol at slaughter [Gr1 (13.07-67.9 ng/mL, n= 24), Gr2 (80.29 - $107.21 \mathrm{ng} / \mathrm{mL}, \mathrm{n}=7)$ and $\mathrm{Gr} 3(133.7-198.04 \mathrm{ng} / \mathrm{mL}, \mathrm{n}=19)$ ]. (Means \pm SE). 
(Fig. 3), and those of $\mathrm{K}(\mathrm{mg} / 100 \mathrm{~g})$ were $765 \pm 71,774 \pm 76$ and $773 \pm 72$ respectiveley (Fig. 4).

\section{Malondialdehyde and catalase activity}

Compared to camels with low circulating cortisol at slaughter (Gr1), those with high (Gr2) and very high (Gr3) cortisol showed a significant increase of meat concentration of MDA at $4 \mathrm{~h}$ postslaughter and 5 and $10 \mathrm{~d}$ postmortem, and a significant decrease of CAT activity in the meat at 5 and $10 \mathrm{~d}$ postmortem during cold storage (Fig. 5). In Gr 1 and Gr 3, MDA levels $(\mathrm{mg} / \mathrm{kg})$ were respectiveley $1.23 \pm 0.85$ and 6.21 $\pm 1.11, \mathrm{P}<0.005$ and $\mathrm{CATa}(\mathrm{UI} / \mathrm{g})$ was respectiveley $183 \pm 27$ and $113 \pm 18, \mathrm{P}<0.05$ at the $5^{\text {th }}$ postmortem $d$ (Fig. 5).

\section{R-value, shrinkage and total haem pigment}

During all cold storage period and at the same stage of cold storage, no significant variations of meat $\mathrm{R}$-value and pourcentage of shrinkage were observed between

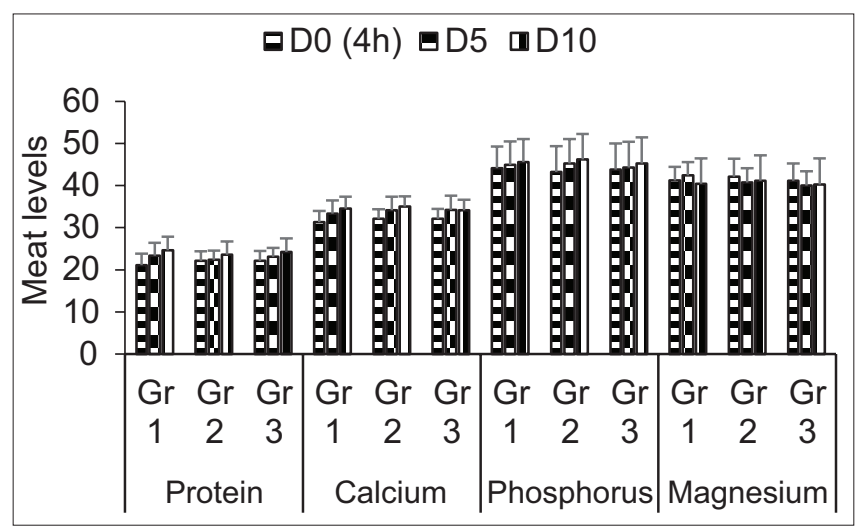

Fig 3. Impact of ageing on potein total ( $\mathrm{g} / 100 \mathrm{~g}$ fresh weight), calcium, phosphorus and magnesium (mg/100g fresh weight) levels in meat at $4 \mathrm{~h}$ postslaughter and 5 and $10 \mathrm{~d}$ postmortem during storage at $4 \pm 1^{\circ} \mathrm{C}$, in 3 groups $(\mathrm{Gr})$ of camels with different serum levels of cortisol at slaughter [Gr1 (13.07-67.9 ng/mL, n= 24), Gr2 (80.29- $107.21 \mathrm{ng} / \mathrm{mL}, \mathrm{n}=7)$ and Gr3 (133.7 $-198.04 \mathrm{ng} / \mathrm{mL}, \mathrm{n}=19)]$. (Means $\pm S E)$.

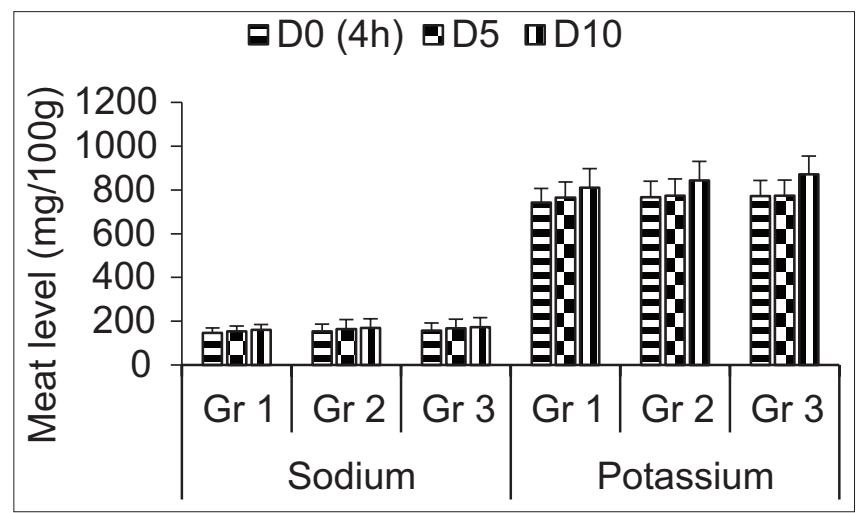

Fig 4. Impact of ageing on sodium and potassium levels $(\mathrm{mg} / 100 \mathrm{~g}$ fresh weight) in meat at $4 \mathrm{~h}$ postslaughter and 5 and $10 \mathrm{~d}$ postmortem during storage at $4 \pm 1{ }^{\circ} \mathrm{C}$, in 3 groups (Gr) of camels with different serum levels of cortisol at slaughter [Gr1 $(13.07-67.9 \mathrm{ng} / \mathrm{mL}, \mathrm{n}=24)$, Gr2 (80.29-107.21 ng/mL, n=7) and Gr3 (133.7-198.04 ng/mL, n= 19)]. (Means \pm SE). groups 1, 2 and 3 (Fig. 6). At $5 \mathrm{~d}$ postmortem, R-value was $1.38 \pm 0.07,1.41 \pm 0.07$ and $1.40 \pm 0.09$ respectiveley in groups 1, 2 and 3. In the same way, shrinkage (\%) was $7.97 \pm 1.55,6.22 \pm 1.48$ and $7.43 \pm 1.52$ respectiveley (Fig. 6). However, in groups 2 and 3 , THP $(\mu \mathrm{g} / \mathrm{g})$ was significantly $(\mathrm{P}<0.05)$ higher by comparison to $\mathrm{Gr} 1(13.39 \pm 1.18$ vs $10.18 \pm 1.06$ and $13.40 \pm 1.21$ vs $10.18 \pm 1.06$ respectiveley at $5 \mathrm{~d}$ postmortem (Fig. 6 ).

A significant correlation between circulating concentrations of cortisol at slughter, and $\mathrm{pH}, \mathrm{DL}, \mathrm{CL}, \mathrm{EC}, \mathrm{MDA}, \mathrm{CATa}$ and THP in camel meat during cold ageing was found (Table 1).

\section{DISCUSSION}

In this study we investigated the relationship between circulating levels of cortisol at slaughter and postmortem

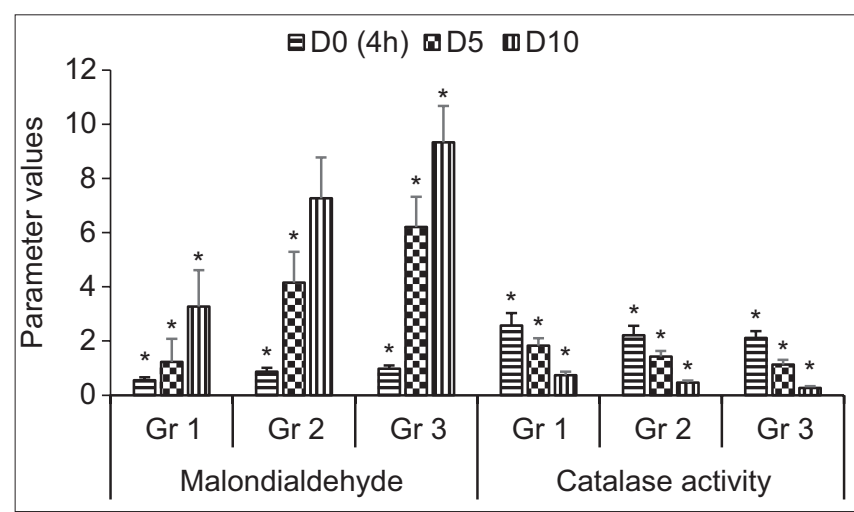

Fig 5. Impact of ageing on malondialdehyde $(\mathrm{mg} / \mathrm{kg})$ and catalase activity $(\mathrm{x} 100 \mathrm{Ul} / \mathrm{g})$ in meat at $4 \mathrm{~h}$ postslaughter and 5 and 10 d postmortem during storage at $4 \pm 1{ }^{\circ} \mathrm{C}$, in 3 groups (Gr) of camels with different serum levels of cortisol at slaughter [Gr1 (13.07-67.9 ng/mL, n= 24), Gr2 (80.29-107.21 ng/mL, $\mathrm{n}=7)$ and Gr3 (133.7- $198.04 \mathrm{ng} / \mathrm{mL}, \mathrm{n}=19)$ ]. (Means $\pm \mathrm{SE}$, ${ }^{*} \mathrm{P}<0.05$, comparison between groups at the same day of cold storage).

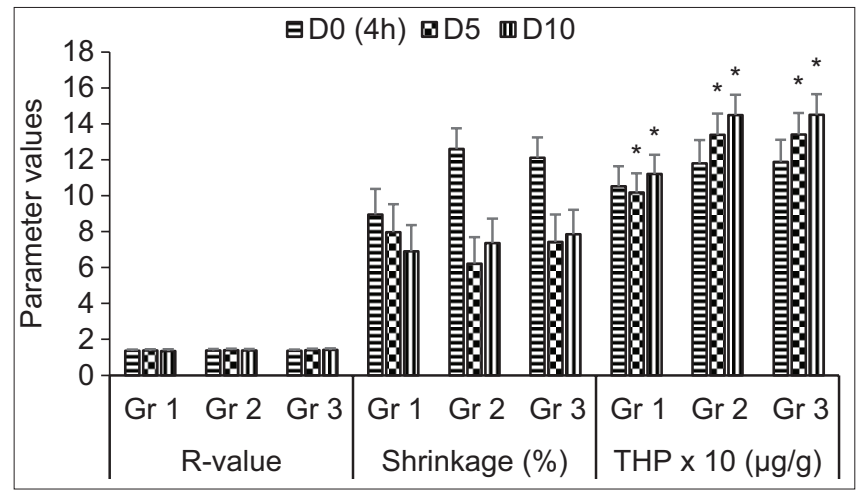

Fig 6. Impact of ageing on R-value, shrinkage and total haem pigment (THP) in meat at $4 \mathrm{~h}$ postslaughter and 5 and $10 \mathrm{~d}$ postmortem during storage at $4 \pm 1{ }^{\circ} \mathrm{C}$, in 3 groups ( $\mathrm{Gr}$ ) of camels with different serum levels of cortisol at slaughter [Gr1 (13.07-67.9 ng/mL, $\mathrm{n}=24)$, Gr2 (80.29-107.21 ng/mL, n= 7) and Gr3 (133.7-198.04 ng/mL, $n=19)]$. (Means $\pm S E$, ${ }^{*} \mathrm{P}<0.05$, comparison between groups at the same day of cold storage). 
Tabite, et al.

Table 1: Correlation coefficients between circulating levels of cortisol at slaughter and quality and stress oxidant parameters in camel met.

\begin{tabular}{|c|c|c|c|c|c|c|c|c|}
\hline & Cortisol & $\mathrm{pH}$ & DL & CL & EC & MDA & CATa & THP \\
\hline Cortisol & 1.0000 & $\begin{array}{l}r=0.781 \\
p=0.000\end{array}$ & $\begin{array}{l}r=0.417 \\
p=0.041\end{array}$ & $\begin{array}{l}r=0.461 \\
p=0.033\end{array}$ & $\begin{array}{l}r=0.432 \\
p=0.044\end{array}$ & $\begin{array}{l}r=0.711 \\
p=0.002\end{array}$ & $\begin{array}{l}r=0.523 \\
p=0.017\end{array}$ & $\begin{array}{l}r=0.471 \\
p=0.018\end{array}$ \\
\hline $\mathrm{pH}$ & & 1.0000 & $\begin{array}{l}r=0.650 \\
p=0.004\end{array}$ & $\begin{array}{l}r=0.547 \\
p=0.014\end{array}$ & $\begin{array}{l}r=0.750 \\
p=0.000\end{array}$ & $\begin{array}{l}r=0.621 \\
p=0.002\end{array}$ & $\begin{array}{c}r=-0.452 \\
p=0.027\end{array}$ & $\begin{array}{l}r=0.894 \\
p=0.014\end{array}$ \\
\hline DL & & & 1.0000 & $\begin{array}{l}r=0.671 \\
p=0.000\end{array}$ & $\begin{array}{l}r=0.598 \\
p=0.003\end{array}$ & $\begin{array}{l}r=0.351 \\
p=0.037\end{array}$ & $\begin{array}{l}r=-0.521 \\
p=0.017\end{array}$ & $\begin{array}{l}r=0.894 \\
p=0.013\end{array}$ \\
\hline$C L$ & & & & 1.0000 & $\begin{array}{l}r=0.721 \\
p=0.001\end{array}$ & $\begin{array}{l}r=0.4713 \\
p=0.018\end{array}$ & $\begin{array}{l}r=-0.545 \\
p=0.015\end{array}$ & $\begin{array}{l}r=0.511 \\
p=0.013\end{array}$ \\
\hline EC & & & & & 1.0000 & $\begin{array}{l}r=0.798 \\
p=0.012\end{array}$ & $\begin{array}{l}r=-0.436 \\
p=0.017\end{array}$ & $\begin{array}{l}r=0.790 \\
p=0.017\end{array}$ \\
\hline MDA & & & & & & 1.0000 & $\begin{array}{l}r=-0.465 \\
p=0.019\end{array}$ & $\begin{array}{l}r=0.713 \\
p=0.040\end{array}$ \\
\hline CATa & & & & & & & 1.0000 & $\begin{array}{l}r=0.721 \\
p=0.042\end{array}$ \\
\hline THP & & & & & & & & 1.0000 \\
\hline
\end{tabular}

DL : drip loss, CL : cooking loss, EC : electrical conductivity, MDA : malondialdehyde, CATa : catalase activity, THP : total haem pigment

physicochemical composition, quality characteristics and oxidant parameters of the camel meat during refrigerated ageing for ten days. Cortisol levels were positively correlated with postmortem $\mathrm{pH}$, DL, CL, EC, MDA and THP, and were negatively correlated with CATa.

Various cruel practices such as rough handling, loading, transport, environmental conditions, soon and unloading are able to impact the animal welfare, resulting in body injuries, body weight shrinkage, muscle injury and fatigue, and degradation of meat quality (Teke et al., 2014). Transport, high stocking density and waiting period before slaughter are an integral part of stress respones which are mediated by an activation of the hypothalamic-pituitaryadrenal axis (HPA) in livestock in general (Swanson and Morrow-Tesch, 2001), and dromedary camel in particular (El khasmi et al., 2013; 2015; Lemrhamed et al., 2018a; 2018b). Transport induces an increase of blood cortisol and the animal could only restore normal value after a rest period, but, a long lairage time could increase cortisol concentrations again in sheep (Liu et al., 2011), calves (Bernardini et al., 2012), camel (Lemrhamed et al., 2018b) and rabbit (Składanowska-baryza et al., 2018).

The biological mechanism of animal stress responsible for high circulating levels of cortisol and mediated by the activation of HPA axis, involves a release of corticotrophinreleasing factor by hypothalamus. This factor, stimulates the adenohypophysis to secrete adrenocorticotropic hormone (ACTH) in blood circulation which in turn stimulates the secretion of cortisol by the adrenal gland (Moberg, 2000). Stress responses are initiated by an activation of the sympathetic system, resulting in a release of noradrenaline and adrenaline (Moberg, 2000). According to Ferguson and Warner (2008), these hormones might influence several muscle or meat parameters, such as, glycogen levels,
$\mathrm{pHu}$, metabolic and structural modifications, proteolytic processes, water holding capacity (WHC), tenderness and flavor.

High circulating levels of cortisol at slaughter tended to increase $\mathrm{pH}, \mathrm{DL}, \mathrm{CL}$ and $\mathrm{EC}$ of meat camel during postmortem cold storage. Significantly higher DL and CL might be due to higher $\mathrm{pHu}$ observed in meat samples during ageing. According to Naveena et al. (2011), the increase in $\mathrm{pH}$ could result from the large number of hydrophilic sites on which several water molecules cling to hydrogen and also ionic bonds at the hydrophilic sites located on the polypeptides.

In pigs, it has been shown that transport stress combined with a short rest period induced an increase in EC of $80 \%$, whereas after the same transport followed by sufficient rest increased EC only by $56 \%$ compared to non transported animals (Cygan-Szczegielniak and Janicki, 2012). In rabbits, a longer transport increased the $\mathrm{pH}$, and the levels of moisture and DL in the meat compared to the shorter transport (Dal Bosco et al., 1997; Trocino et al., 2003).

In pig, preslaughter stress had been found able to reduce the pork quality by decreasing muscle glycolytic potential (muscle glycogen content before slaughter), tenderness and WHC (Gregory, 2003), and increasing plasma lactate, cortisol, muscle temperature, postmortem acidification, and $\mathrm{pHu}$ (Hambrecht et al., 2005). It was reported that transport and waiting before slaughter are responsible for a depletion of glycogen then a low levels of postmortem acidity in the muscle (Gregory, 2003; Campo et al., 2010). This depletion impacts meat $\mathrm{pHu}$, tenderness, WHC and color (Apple et al., 1995; Mounier et al., 2006). In cattle, Teke et al. (2014) have reported a lowest muscle pHu after a rest period of $72 \mathrm{~h}$, and a highest $\mathrm{pHu}$ after $24 \mathrm{~h}$ waiting 
duration. In addition, in bulls, Mounier et al. (2006) have studied the effets of three period of rest (1,17 and $40 \mathrm{~h}$ ) before slaughter, and have found a negative correlation between $\mathrm{pHu}$ and lairage time. In pig, transport stress decreased significantly the antemortem levels of muscle glycogen (Leheska et al., 2003), however, in the same species, Brown et al. (1999) found no effect of stress transport on the muscle glycogen.

Other authors think that muscle depletion of glycogen during long preslaughter feed and water restriction had been able to increase the meat $\mathrm{pHu}$ (Warris, 1990). So, according to Gallo et al. (2003) a long period of rest had altered several parameters of meat quality. In fact, after transport, the meat $\mathrm{pHu}$ increased after a lairage time of 48 hs in sheep (Toohey and Hopkins, 2006), and 9 hs in pig (Pérez et al., 2002). In the same way, meat of lambs who had waited $24 \mathrm{~h}$ in lairage had been darker than that of lambs who had waited $1 \mathrm{~h}$ (Jacob et al., 2005). These authors explained their findings by a possible depletion of glycogen stores in the muscle during the waiting period and food privation before slaughter.

In cattle, the DL of meat from animals that have spent $24 \mathrm{~h}$ in lairage was lower than that from animals that have been resting for $48 \mathrm{~h}$ or $72 \mathrm{~h}$ (Teke et al., 2014). However, in the same animals and conditions, the lairage time showed no influence on CL, WHC and tenderness (Teke et al., 2014). The DL and pHu as an important quality parameters are ifluenced by antemortem muscle content of glycogen, and increase significantly in meat when fasting time and lairage period increase before slaughter (Terlouw and Rybarzcyk, 2008).

In goat, it had been reported that a road transport for $2 \mathrm{~h}$ in a worm atmosphere induced higher circulating levels of cortisol and adrenaline, and higher $\mathrm{pHu}$, expressed juice, CL percentage and shear force in the meat (Kadim et al., 2006). Similarly, in sheep, a rough road transport for $4 \mathrm{~h}$ (Ruiz-De-La-Torre et al., 2001), or a restraint-stresse (Apple et al., 1995) induced a significant increase of meat $\mathrm{pHu}$. Furthermore, Miranda-de la Lama et al. (2011) had also reported that when the road was unpaved, transported lambs showed a significant increase of circulating cortisol, lactate and glucose, and meat CK levels and pHu compared with lambs transported on paved roads. These responses might be explained by a impact of cortisol. In fact, in lambs, injection of cortisol induced a significant increase of glucose metabolism, temperature, $\mathrm{pH}$ and $\mathrm{WHC}$ of fresh meat (Pighin et al., 2013). In addition, WHC, proteolysis, lipid oxidation and color of meat are largely influenced by the Postmortem $\mathrm{pH}$ and temperature kinetics of muscle, and are able to determine the sensory aspects of meat, then the satisfaction of the consumer (Bee et al., 2007; Ferguson et al., 2008). Furthermore, according to Offer and Knight (1988), the variations of postmortem $\mathrm{pH}$ and temperature in the muscle could impact shrinking myofibrils and therefore the WHC during ageing of meat.

The preslaughter stress and cold ageing showed no effect on the chemical composition of the camel meat. Barka et al. (2016) have studied the effect of transport distance on some physicochemical parameters in 3 muscles (triceps, oblique and diaphragm) in the camel. The authors have found a significant decrease of glycogen content and a significant increase of $\mathrm{pHu}$ in these muscles when when the distance of transportation increased, without any significant variations of proteins, ashes, dry mater and moisture. On the contrary, meat from rabbits having been road transported for a long journey showed a significant increase of moisture compared to rabbits having submitted to short transpot (Dal Bosco et al., 1997).

In the study reported here, MDA contents increased significantly, whereas CAT activity decreased significantly during the postmortem stages of cold storage, but, the camels with high circulating cortisol at slaughter showed the highest levels of MDA and the lowest activities of CAT in their meat. In the camel, Barka et al. (2016) have evaluated the impact of stress induced by transport distance on muscle biomarkers, and have found that the levels of MDA increased while the CATa decreased significantly in the muscle when the transport distance increased. The oxidation of oxymyoglobin and lipids, as well as microbial contaminations leads to discoloration, DL and the production of potentially toxic compounds (Aidani et al., 2014). In the camel meat, the continuous increase of MDA levels observed during cold storage (Tabite et al., 2018), may be explained by formation of free short-chain fatty acids and unstable lipid hydroperoxide by microbial enzymatic hydrolysis (Gheisari et al., 2009). Lipid peroxidation of raw and cooked meat products of camel is one of the main causes of deterioration in the quality during cold and frozen ageing (Abdelhadi et al., 2013). In camels, Maqsood et al. (2015) studied protein and lipid characterization of fresh meat during $9 \mathrm{~d}$ of cold ageing at $4^{\circ} \mathrm{C}$. They found that camel meat undergoes a lipid oxidation at a more pronounced level on the $3^{\text {rd }}$ day of cold ageing, then a low peroxidation index, the $9^{\text {th }}$ day.

The results showed no significant differences in postmortem $\mathrm{R}$-value and THP contents during cold storage of meat, between camel groups with different circulating levels of cortisol at slaughter. As an indicator of ATP level, R-value is defined as the ratio of adenine nucleotidase (ATP) to inosine nucleotidase (IMP) (Khan and Frey, 1971). It is 
largely knowen that muscle levels of THP are recognized to impact the lightness of meat (Fletcher, 2002), thus, the levels of THP were negatively correlated with lightness in poultry meat (Sirri et al., 2009) and meat products (Guzman et al., 1995). In the dromedary camels, the high and very high cortisol groups showed high meat levels of THP when compared with the low cortisol group. So, the meat of camels with high cortisol at slaughter might be darker than that in low cortisol ones.

\section{CONCLUSION}

Taken together, our results showed that in the dromedary camel, high and very high circulating levels of cortisol at slaughter influenced the postmortem $\mathrm{pH}$, antioxidant status and quality characteristics of its meat during cold ageing. It could be suggested that measuring serum cortisol at exsanguination may be useful to predict the postmortem storage conditions and quality value of camel meat.

\section{ACKNOWLEDGMENTS}

The authors thank the prefectural veterinary service of Casablanca and the President of urban municipalities of Casablanca to carry out this investigation.

\section{Author's contributions}

R. T. was involved in conception and design of study and redaction. A. L. was involved in documentation, blood sampling and analysis of results. M. F. was involved in blood sampling, physicochemical and radioimmunological analysis. N. E. was involved in radioimmunological analysis. A. B. was involved in processing and statistical analysis of results. B. F. was involved in revision of experimental design and redaction. M. E. made a major contribution by supervising this work.

\section{REFERENCES}

Abdelhadi, O. M. A., S. A. Babiker, J. F. Hocquette, B. Picard, D. Durand and B. Faye. 2013. Effect of ageing on meat quality of the one humped camel (Camelus dromedarius). Emir. J. Food Agric. 25: 150-158.

Aebi, H. 1974. Evaluation de l'activité de la catalase. In: Methods of Enzymatic Analysis, $2^{\text {nd }}$ ed., Vol. 2. H.U. Bergmeyer. Verbag chimie $\mathrm{GmbH}$. Weinheim, pp. 673-684.

Aidani, E., B. Aghamohammadi, M. Akbarian, A. Morshedi, M. Hadidi, N. Ghasemkhani and A. Akbarian. 2014. Effect of Chilling, Freezing and Thawing on Meat Quality: A Review. Int. J. Biosci. 5: $159-169$.

AOAC. 2000. Association of Official Analytical Chemists. Official Methods of Analysis, AOAC International, Gaithersburg, MD, USA.

Apple, J. K., M. E. Dikeman, J. E. Minton, R. M. McMurphy, M. R. Fedde, D. E. Leith and J. A. Unruh. 1995. Effects of restraint and isolation stress and epidural blockade on endocrine and blood metabolic status, muscle glycogen metabolism, and incidence of dark-cutting longissimus muscle of sheep. J. Anim. Sci. 73: 2295-307.

Barka, K., M. Farh, F. Riad, E. H. Tahri, A. Belhouari and M. El Khasmi. 2016. Impact of transport distance on some stress biomarkers levels in camel meat. MOJ Food Process Technol. 2: 130-134.

Bee, G., A. L. Anderson, S. M. Lonergan and E. Huff-Lonergan. 2007. Rate and extent of $\mathrm{pH}$ decline affect proteolysis of cytoskeletal proteins and water holding capacity in pork. Meat Sci. 76: 359-365.

Bernardini, D., G. Gerardi, A. Peli, L. Nanni Costa, M. Amadori and S. Segato. 2012. The effects of different environmental conditions on thermoregulation and clinical and hematological variables in long-distance road-transported calves. J. Anim. Sci. 90: 1183-1191.

Botsoglou, N. A., D. J. Fletouris, G. E. Papageorgiou, V. N. Vassilopoulos, A. J. Mantis and A. G. Trakatellis. 1994. Rapid, sensitive, and specific thiobarbituric acid method for measuring lipid-peroxidation in animal tissue, food and feedstuff samples. J. Agric. Food Chem. 42: 1931-1937.

Brown, S. N., T. G. Knowles, J. E. Edwards and P. D. Warriss. 1999. Behavioural and physiological responses of pigs to being transported for up to 24 hours followed by six hours recovery in lairage. Vet. Rec. 145: 421-426.

Campo, M., G. Brito, J. S. de Lima, P. Hernandez and F. Montossi. 2010. Finishing diet, temperament and lairage time effects on carcass and meat quality traits in steers. Meat Sci. 86: 908-914.

Cygan-Szczegielniak, D. and B. Janicki. 2012. Effect of age and sex of roe deer on tenderness and other quality characteristics of longissimus lumborum muscle. Ywność Nauka Technol. Jakość. 6: 127-137.

Dal Bosco, A., C. Castellini and M. Bernardini. 1997. Effect of transportation and stunning method on some characteristics of rabbit carcasses and meat. World Rabbit Sci. 5: 115-119.

El Khasmi, M., F. Riad, A. Safwate, E. Tahri, M. Farh, N. El Abbadi, V. Coxam and B. Faye. 2010. Effects of preslaughter stress on meat quality and phosphocalcic metabolism in Camels (Camelus dromedarius). J. Camelid Sci. 3: 33-38.

El Khasmi, M., Y. Chakir, F. Riad, A. Safwate, E. Tahri, M. Farh, N. ElAbbadi, R. Abouhafs and B. Faye. 2013. Effects of transportation stress during the hot-dry season on some haematological and physiological parameters in moroccan dromedary camels (Camelus dromedarius). J. Life Sci. USA. 7: 13-25.

El Khasmi, M., Y. Chakir, R. Bargaâ, K. Barka, I. Lektib, N. El Abbadi, A. Belhouari and B. Faye. 2015. Impact of transport distance on stress biomarkers levels in dromedary camel (Camelus dromedarius). Emir. J. Food Agric. 27: 507-512.

Engy, F. Z. 2017. The quality characteristics of camel sausage formulated with different levels of whey protein powder. Int. J. Environ. Agric. Biotechnol. 2: 2481-2486.

FAWC. 1991. Report on the European Commission Proposals on the Transport of Animals. MAFF Publications, London.

Ferguson, D. M. and R. D. Warner. 2008. Have we underestimated the impact of pre-slaughter stress on meat quality in ruminants? Meat Sci. 80: 12-19.

Fletcher, D. L. 2002. Poultry meat quality. World Poult. Sci. J. 58: 131-145.

Gallo, C., G. Lizondo and T. G. Knowles. 2003. Effects of journey and lairage time on steers transported to slaughter in Chile. Vet. Rec. 152: 361-364.

Gheisari, H. R., M. Aminlari and S. H. Shekarforoush. 2009. A 
comparative study of the biochemical and functional properties of camel and cattle meat during frozen storage. Vet. Arhiv. 79: 51-68.

Gheisari, H. R. and V. R. Ranjbar. 2013. Antioxidative and antimicrobial effects of garlic in ground camel meat. Turk. J. Vet. Anim. Sci. 36: 13-20.

Gregory, N. G. 2003. Animal Welfare and Meat Science. CABI Publishing, USA, pp. 64-92.

Guzman, J. C., K. W. McMillin, T. D. Bidner, S. Dugas-Sims and J. S. Godber. 1995. Texture, color and sensory characteristics of ground beef patties containing bovine blood proteins. J. Food Sci. 60: 657-660.

Hambrecht, E., J. J. Eissen, D. J. Newman, C. H. M. Smits, L. A. Den Hartog and M. W. A. Verstegen. 2005. Negative effects of stress immediately before slaughter on pork quality are aggravated by suboptimal transport and lairage conditions. J. Anim. Sci. 83: 440-448.

Honikel, K. O. 1998. Reference methods for the assessment of physical characteristics of meat. Meat Sci. 49: 447-457.

Honikel, K. O. and C. A. Fisher. 1977. A rapid method for the detection of PSE and DFD porcine muscles. J. Food Sci. 42: 1633-1636.

Hur, S. J, B. W. Ye, J. L. Lee, Y. L. Ha, G. B. Park and S. T. Joo. 2004. Effects of conjugated linoleic acid on color and lipid oxidation of beef patties during cold storage. Meat Sci. 66: 771-775.

Immonen, K., M. Ruusunen, K. Hissa and E. Puolanne. 2000. Bovine muscle glycogen concentration in relation to finishing diet, slaughter and ultimate $\mathrm{pH}$. Meat Sci. 55: 25-31.

Jacob, R. H., P. J. Walker, J. W. Skerritt, R. H. Davidson, D. L. Hopkins, J. M. Thompson and D. W. Pethick. 2005. The effect of lairage time on consumer sensory scores of the $\mathrm{M}$. longissimus thoracis et lumborum from lambs and lactating sheep. Aust. J. Exp. Agric. 45: 535-542.

Kadim, I. T., O. Mahgoub, A. Al-Kindi, W. Al-Marzooqi and N. M. Al-Saqri. 2006. Effects of transportation at high ambient temperatures on physiological responses, carcass and meat quality characteristics of three breeds of Omani goats. Meat Sci. 73: 626-634.

Kadim, I. T., O. Mahgoub and W. Al-Marzooqi. 2008. Meat quality and composition of longissimusthoracis from Arabian camel (Camelus dromedarius) and Omani beef: A comparative study. J. Camelid Sci. 1: 37-47.

Kannan, G., T. H. Terrill, B. Kouakou, O. S. Gazal, S. Gelaye, E. A. Amoah and S. Samake. 2000. Transportation of goats: Effects on physiological stress responses and live weight loss. J. Anim. Sci. 78: 1450-1457.

Khan, A. W. and A. R. Frey. 1971. A simple method for following rigor mortis development in beef and poultry. Can. Inst. Food Technol. J. 4: 139-142.

Leheska, J. M., D. M. Wulf and R. J. Maddock. 2003. Effects of fasting and transportation on pork quality development and extent of postmortem metabolism. J. Anim. Sci. 81: 3194-3202.

Lemrhamed, A., M. Farh, F. Riad, N. El Abbadi, E. H. Tahri, A. Belhouari, B. Faye and M. El Khasmi. 2018a. Evaluation of stress responses induced by the loading density in dromedary camel (Camelus dromedarius). Emir. J. Food Agric. 30: 803-808.

Lemrhamed, A., M. Farh, F. Riad, N. El Abbadi, E. H. Tahri, B. Faye and M. El Khasmi. 2018b. Impact of lairage time at slaughterhouse on physiological biomarkers of stress in dromedary camel (Camelus dromedarius). In: S. Abdelmalek, and K. Faouzi (Eds.), Recent Advances in Camelids Biology, Health and Production: Proceedings of the $5^{\text {th }}$ Conference ISOCARD 2018. ISOCARD, Laâyoune, pp. 323-324.

Liu, H. W., R. Z. Zhong, D. W. Zhou, H. X. Sun and C. S. Zhao.
2011. Effects of lairage time after road transport on some blood indicators of welfare and meat quality traits in sheep. J. Anim. Physiol. Anim. Nutr. (Berl). 96: 1127-1135.

Maqsood, S., A. Abushelaib, K. Manheem and I. T. Kadim. 2015. Characterisation of the lipid and protein fraction of fresh camel meat and the associated changes during refrigerated storage. J. Food Compos. Anal. 41: 212-220.

Miranda-de la Lama, G. C., P. Monge, M. Villarroel, J. L. Olleta, S. García-Belenguer and G. A. María. 2011. Effects of road type during transport on lamb welfare and meat quality in dry hot climates. Trop. Anim. Health Prod. 43: 915-922.

Moberg, G. P. 2000. Biological response to stress implications to animal welfare. In: G. P. Moberg, and J. A. Mench (Eds.), The Biology of Animal Stress Basic Principles and Implications for Animal Welfare. CABI Publishing, Oxon, UK, pp. 1-22.

Mounier, L., H. Dubroeucq, S. Andanson and I. Veissier. 2006. Variations in meat $\mathrm{pH}$ of beef bulls in relation to conditions of transfer to slaughter and previous history of the animals. J. Anim. Sci. 84: 1567-1576.

Naveena, B. M., A. R. Sen, M. Muthukumar, Y. Babji and N. Kondaiah. 2011. Effect of ammonium hydroxide on the quality of ground buffalo meat patties. Meat Sci. 87: 315-320.

Offer, G. and P. Knight. 1988. The structural basis of water-holding in meat. Part 1: General principles and water uptake in meat processing. In: R. Lawrie (Ed.), Developments in Meat Science, Vol. 4. Elsevier Applied Science. London, New York, pp. 64-190.

Pérez, M. P., J. Palacio, M. P. Santolaria, M. D. C. Aceña, G. Chacón, M. T. Verde, J. H. Calvo, M. P. Zaragoza, M. Gascón and S. GarcíaBelenguer. 2002. Influence of lairage time on some welfare and meat quality parameters in pigs. Vet. Res. 33: 239-250.

Pighin, D. G., S. A. Cunzolo, M. Zimerman, A. A. Pazos, E. Domingo, A. J. Pordomingo and G. Grigioni. 2013. Impact of adrenaline or cortisol injection on meat quality development of merino hoggets. J. Integr. Agric. 12: 1931-1936.

Pohja, M. S. and F. P. Niinivaara. 1957. Die bestimmung der wasserbindund des fleishesmittels der konstantdruckmethode. Fleischwirtschaft. 9: 193-195.

Ruiz-de-la-Torre, J. L., A. Velarde, A. Diestre, M. Gispert, S. J. G. Hall, D. M. Broom and X. Manteca. 2001. Effects of vehicle movements during transport on the stress responses and meat quality of sheep. Vet. Rec. 148: 227-229.

Saeb, M., H. Baghshani, S. Nazifi and S. Saeb. 2010. Physiological response of dromedary camels to road transportation in relation to circulating levels of cortisol, thyroid hormones and some serum biochemical parameters. Trop. Anim. Health and Prod. 42: $55-63$.

SAS. 2005. Statistical Analysis System Package. SAS Institute, Inc., Cary, NC.

Silva, J. A., L. Patarata and C. Martins. 1999. Influence of ultimate $\mathrm{pH}$ on bovine meat tenderness during ageing. Meat Sci. 52: 453-459.

Sirri, F., M. Bianchi, M. Petracci and A. Meluzzi. 2009. Influence of partial and complete caponization on chicken meat quality. Poult. Sci. 88: 1466-1473.

Składanowska-Baryza, J., A. Ludwiczak, E. P. Nska-Oszmałek, P. Kołodziejski, M. Bykowska and M. Stanisz. 2018. The effect of transport on the quality of rabbit meat. Anim. Sci. J. 89: 713-721.

Swanson, J. C. and J. Morrow-Tesch. 2001. Cattle transport: Historical, research, and future perspectives. J. Anim. Sci. 79: E102-E109.

Tabite, R., K. Barka, M. Farh, F. Riad, N. El Abbadi, E. H. Tahri, A. Belhouari, B. Faye and M. El Khasmi. 2018. Effect of postmortem ageing on quality parameters, contents of proteins, 
lipids and 25-hydroxyvitamin D, and oxidative stability in the camel meat during cold storage. JASTA. 8: 323-332.

Teke, B., F. Akdag, B. Ekiz and M. Ugurlu. 2014. Effects of different lairage times after long distance transportation on carcass and meat quality characteristics of Hungarian Simmental bulls. Meat Sci. 96: 224-229.

Terlouw, E. M. C. and P. Rybarzcyk. 2008. Explaining and predicting differences in meat quality through stress reactions at slaughter: The case of Large White and Duroc pigs. Meat Sci. 79: 795-805.

Toohey, E. S. and D. L. Hopkins. 2006. Effects of lairage time and electrical stimulation on sheep meat quality. Aust. J. Exp. Agric.
46: 863-867.

Trocino, A., G. Xiccato, P. I. Queaque and A. Sartori. 2003. Effect of transport duration and gender on rabbit carcass and meat quality. World Rabbit Sci. 11: 23-32.

Warriss, P. D. 1979. The extraction of haem pigments from fresh meat. J. Food Technol. 14: 75.

Warriss, P. D. 1990. The handling of cattle pre slaughter and its effect on carcass and meat quality. Appl. Anim. Behav. Sci. 28: 171-186.

Warriss, P. D. 2003. Optimal lairage times and conditions for slaughter pigs: A review. Vet. Res. 153: 170-176. 